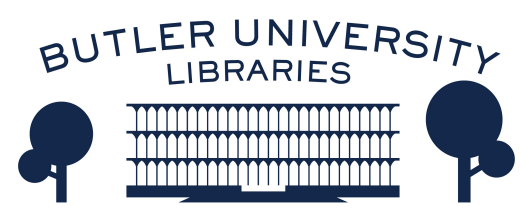

Journal of Hindu-Christian Studies

Volume 17

Article 10

January 2004

\title{
Viewpoint: Pastors, Pujaris, and Swamis: Hindu-Christian Encounter in a Classroom
}

M. Thomas Thangaraj

Follow this and additional works at: https://digitalcommons.butler.edu/jhcs

Part of the Religion Commons

\section{Recommended Citation}

Thangaraj, M. Thomas (2004) "Viewpoint: Pastors, Pujaris, and Swamis: Hindu-Christian Encounter in a Classroom," Journal of Hindu-Christian Studies: Vol. 17, Article 10.

Available at: https://doi.org/10.7825/2164-6279.1319

The Journal of Hindu-Christian Studies is a publication of the Society for Hindu-Christian Studies. The digital version is made available by Digital Commons @ Butler University. For questions about the Journal or the Society, please contact cbauman@butler.edu. For more information about Digital Commons @ Butler University, please contact digitalscholarship@butler.edu. 


\title{
VIEWPOINT Pastors, Pujaris, and Swamis: Hindu-Christian Encounter in a Classroom
}

\author{
M. Thomas Thangaraj \\ Emory University
}

I HAVE been teaching a course titled "Christian Encounter with Hinduism," at Candler School of Theology, Emory University, Atlanta, since 1988. Students who enroll in this course are mostly those who are pursuing the Master of Divinity program with a view to becoming pastors in Christian congregations or chaplains in colleges and hospitals. Some others are in the process of discerning their vocation as theologians, teachers, counselors, or informed laypersons.

\section{Reason for Encounter}

The rationale for offering such a course to theological students is manifold. First, taking seriously the dictum that "if you know only one religion, you know none," every Christian theological student needs to study and understand at least one religion other than Christianity to deepen and enrich his or her own Christian faith. Second, given the religiously pluralistic character of our communities, Christian pastors find themselves in situations of offering spiritual care to people who do not belong to the Christian religious tradition. In such occasions, they need to be informed of and sympathetic to the other's religious persuasions, and not view those situations as "evangelistic"1 moments. Third, Christian theological reflection cannot escape, in today's setting, the question of religious pluralism, and therefore a study of HinduChristian encounter could trigger the students' theological imagination and enable them to reflect creatively on a theology of religions.

\begin{abstract}
Dr. M. Thomas Thangaraj is the D.W. \& Ruth Brooks Associate Professor of World Christianity at the Candler School of Theology, Emory University, Atlanta. He earned his Doctor of Theology degree from Harvard University. He has given guest lectures in United Kingdom, Philippines, Japan, Sweden, Denmark, Norway, Germany, Myanmar (Burma), Taiwan, and in several places in India and United States. He has been actively involved in programs of inter-religious dialogue both at the national and international level. His most recent publications are The Crucified Guru: An Experiment in Cross-Cultural Christology (Abingdon Press, 1994), Relating to People of Other Religions: What Every Christian Needs to Know (Abingdon Press, 1997), and The Common Task: A Theology of Christian Mission (Abingdon Press, 1999). His current research focuses on the theological themes that emerge in Indian Christians' encounter with the reality of religious pluralism. He is at present a member of the think-tank, "Thinking Together" that brings theologians of various faiths to think theologically together annually for three years, sponsored by the Office of Inter-Religious Relations, World Council of Churches, Geneva, Switzerland, beginning from January 2000. Currently Professor Thangaraj is teaching at Emory only during spring semesters, and is associated with the work of the Bishop Stephen'Neill Research and Study Centre, Tirunelveli, India during fall semesters.
\end{abstract}




\section{Process of Encounter}

At the beginning of the course, students answer the following set of questions: "What are your early images of Hindus and Hinduism? Where did these images come from? Have you known any Hindus? If so, what were your impressions and thoughts?" The students' answers reveal a rich variety of pre-understandings of Hinduism. Students who have taken courses on World Religions during their undergraduate study exhibit a sufficient knowledge of Hinduism. Some have met a few Hindus. However, their overall impressions of Hinduism are informed by the brief and superficial representations of Hinduism and Hindus in the mass media. For example, many referred to $\mathrm{Apu}$ in the cartoon show, Simpsons, and to Indiana Jones movies. Others associate Hindu faith simply and wholly with the dot on the forehead, the smell of Indian spices, Mahatma Gandhi, or vegetarianism.

The course begins with lectures and readings on the history, themes, and practices of Hinduism. The readings include the Bhagavad-Gita in English translation, in addition to secondary materials. The students pay a visit to the Hindu Temple of Atlanta. Next comes a survey of the ways in which the Christian encounter with Hinduism had taken place in the past. This leads to examining the writings of three contemporary theologians - Diana Eck, Francis Clooney, and Thomas Thangaraj ${ }^{2}$ as illustrative of a healthy, dialogical, and productive mode of encounter with Hinduism. While students are reading Eck, Clooney, and Thangaraj, they also engage in conversation with Hindus who visit the class and expound their own way of living out the Hindu faith. The visitors include both scholars and ordinary practitioners of Hindu faith. The course ends with an attempt to formulate a Christian theology of religions that can promote and sustain a fruitful and dialogical encounter between Hindus and Christians.

\section{Learning through Encounter}

As a teacher, I have experienced this course both as a sharpening of my scholarly and pedagogical vocation and as an enhancing of my spiritual journey toward wholeness and inclusivity. However, several questions haunt me when I present the Hindu tradition at its best and offer it to my students as a religion worthy of understanding, appreciation, and even embrace. If Hinduism is as good and wonderful as my lectures indicate, why am I a Christian? Why did my ancestors leave Hinduism 200 years ago and embrace the Christian faith? How do I reconcile my pungent criticism of early missionary attitudes to Hinduism and cases of proselytism with my celebration of my Indian Christian heritage? Does my place in the lower rungs of the caste ladder shape my understanding of Hinduism, quite often in a negative manner? These questions assist me to understand my own Christian faith in a deeper manner, engage in a scholarship that is responsible in its critique, and develop a pedagogical style that combines personal story and critical thinking.

My students, on the other hand, experience this course as a widening of their knowledge of the world, a sharpening of their theological thinking, and a defining of their vocation as ministers in the Christian church. This happens primarily through their visiting the Hindu temple and their meeting of and conversation with the Hindu visitors to the class. These lively encounters with places and persons triggers and enhances the learning process more than all the readings and lectures! Quite often, my students look for their counterpart - the pastor - in the Hindu tradition. They meet the pujari or priest in the temple and find that he does not function like a Christian pastor. Later they encounter a Hindu philosopher and a Hindu monk, and discover 
$68 \mathrm{M}$. Thomas Thangaraj

that even though they share a similar teaching role with them, the Christian minister is not like a Hindu monk! This experience gives them an opportunity to think through their own vocation in depth and bring clarity to it.

Finally, the Hindu visitors to my class have their stories of learning too. The visitors find their conversations with Christians in a classroom setting to be refreshing and enjoyable because it is free from the burden of Christian preoccupation with evangelism Moreover, they see these occasions as incentives to think through what it means to be a Hindu and to articulate one's faith, and thus they emerge from their visit to this class as budding Hindu theologians!

It has become clear to me that there can never be an encounter between "Christianity" and "Hinduism" as religions in a classroom. Rather, there is a miltitude of occasions, settings, and situations for Christians and Hindus to encounter one another in creative dialogue, and thus enhance and enrich one another's journey toward the Divine. This classroom is one such.

\section{Notes}

1. By the term, "evangelistic," I mean the mandate to announce the "good news" of Jesus Christ and to invite people to join the Christian religious tradition. There is a tendency among some Christians to view any and every contact with people of other religions as opportunities to preach to them about the Christian faith along with a call to conversion.

2. Diana Eck, Encountering God: A Spiritual Journey from Bozeman to Benares, Boston, Beacon Press, 1993; Francis X. Clooney, Hindu Wisdom for All God's Children, Maryknoll, NY, Orbis Press, 1998; M. Thomas Thangaraj, The Crucified Guru: An Experiment in Cross-Cultural Christology, Nashville, Tennessee, Abingdon Press, 1994. 